\title{
HUBUNGAN PENGETAHUAN, SIKAP, PERILAKU KEPALA KELUARGA DENGAN PENGAMBILAN KEPUTUSAN PENGOBATAN TRADISIONAL DI DESA RAMBAH TENGAH HILIR KECAMATAN RAMBAH KABUPATEN ROKAN HULU, RIAU
}

\author{
Fitriana Desni, Trisno Agung Wibowo, Rosyidah \\ Fakultas Kesehatan Masyarakat, Universitas Ahmad Dahlan, Yogyakarta
}

\begin{abstract}
Background: Indonesia has long recognized and uses traditional medicine as an effort in tackling health problems. Person's behavior in decision-making related to knowledge and attitude of a person in seeing a problem. The interviews found $30 \%$ of the population still believes in traditional medicine than medical treatment for about public trust traditional medicine, get counseling about medical treatment and health service facilities are difficult to reach. The purpose of this research is to know the relationship of knowledge, attitudes, behavior family heads with the traditional treatment decision-making in the village of Central Rambah Hilir, Rokan Hulu, Riau.

Methods: This study was observational analytic research with cross sectional design. Population studies of the head of the family who are living in the village of Lower Central District Rambah Rokan Hulu in Riau. Sampling technique it was by random sampling to multistage sampling approach. Samples obtained as many as 86 people. Descriptive data analyzed using frequency distribution tables and analytically to determine the relationship between two variables with chisquare.

Results: Result of research indicate that there was relation having a meaning amongh knowledge household with the decision making of traditional medicine equal to $p=0,003$. There was relation between of among attitude household and with the decision making of traditional medicine equal to $p=0,000$. There is relation having a meaning of among behavior household with occurrence of the decision making of traditional medicine equal to $p=0,000$.

Conclusion: All accurate free variables there was relation between knowledge, attitudes, behavior and decision making of traditional medicine.
\end{abstract}

Keywords: Knowledge, attitudes, behaviors, and traditional medical decision making.

\section{PENDAHULUAN}

Pembangunan yang sedang berlangsung sekarang ini pada hakikatnya adalah pembangunan manusia Indonesia seutuhnya dan pembangunan seluruh manusia untuk menuju masyarakat yang adil dan makmur berdasarkan Undang-Undang Dasar 1945. Keberhasilan pembangunan kesehatan ditandai dengan masyarakat yang hidup dalam lingkungan yang sehat dan berperilaku sehat, memiliki kemampuan untuk menjangkau pelayanan kesehatan bermutu secara adil dan merata serta memiliki derajat kesehatan yang setinggi-tingginya. Peran pemerintah atau pihak luar dalam memelihara dan melindungi kesehatan masyarakat hanyalah sebagai fasilitator, motivator, atau stimulator. Sebaiknya, setiap orang baik individu, kelompok, maupun masyarakat, mempunyai kewajiban dan tanggung jawab untuk melindungi kesehatan dan menjaga kesehatan dirinya sendiri dari segala ancaman penyakit dan masalah kesehatan yang lain ${ }^{1}$. 
Pengobatan di Indonesia mengenal dua sistem pengobatan yaitu pengobatan medis dan pengobatan tradisional. Pengobatan medis sering menggunakan obat, dilakukan oleh tenaga yang mendapat pendidikan formal kesehatan dengan menggunakan cara, alat atau bahan yang sudah mendapat standar medis/kedokteran. Pengobatan tradisional adalah pengobatan yang dilakukan secara tradisional, turuntemurun, berdasarkan resep nenek moyang, adat-istiadat, kepercayaan, atau kebiasaan setempat, baik bersifat magic maupun pengetahuan tradisinal.

Berkembangnya teknologi dalam dunia mempermudah masyarakat Indonesia dalam melakukan upaya pengobatan secara medis, namun belum secara menyeluruh masuk ke wilayah Indonesia, salah satunya adalah di Desa Rambah Tengah Hilir yang sebagian masyarakatnya masih mempercayai pengobatan tradisional. Pada mulanya semua pertolongan dilakukan oleh "dukun" atau mereka yang mengkhususkan diri dalam pertolongan persalinan, tanpa membolehkan tenaga medis lainnya ikut melakukan hal tersebut. Pengetahuan yang serba terbatas sering menimbulkan terjadinya kematian ibu maupun bayi, terutama pada pertolongan pertama yang sangat diperlukan. Ukuran kemampuan pelayanan kesehatan satu negara ditetapkan berdasarkan angka kematian ibu dan angka kematian karena melahirkan. Pertolongan di Indonesia sekitar $75-80 \%$ masih ditolong dukun terutama di pedesaan. Penyebab kematian terjadi terutama karena perdarahan, infeksi dan keracunan hamil, serta terlambatnya system rujukan. Menjelang abad ke 21 yang bercirikan ilmu pengetahuan dan teknologi, maka kualitas sumber daya manusia menjadi sangat penting sehingga diharapkan lahir generasi yang sehat rohani dan jasmani serta mampu secara maksimal untuk mengembangkan diri².

Masalah pengambilan keputusan dalam melakukan pengobatan merupakan hal yang sangat berpengaruh terhadap kesehatan. Kepala keluarga memegang peranan penting dalam hal pengambilan keputusan, seharusnya memiliki pengetahuan yang baik sebagai penanggung jawab keluarga, sehingga dapat membantu menentukan sikap terhadap apa yang hendak dilakukan. Terlebih dalam hal menentukan pengobatan, suatu hal yang harus dipertimbangan dengan matang baik buruk serta efek yang ditimbulkan.

Dalam mengatasi masalah kesehatan yang terjadi didalam keluarga, yang mengambil keputusan untuk pemecahan masalahnya adalah kepala keluarga atau anggota keluarga yang dituakan, karena kepala keluarga mempunyai peran yang sangat penting dalam keluarga ${ }^{3}$.

Berdasarkan hasil observasi yang telah dilakukan pada hari Rabu tanggal 23 September 2009 di Desa Rambah Tengah Hilir Kecamatan Rambah Kabupaten Rokan Hulu, Riau, terdapat jumlah penduduk sebesar 2.391 jiwa dengan 604 kepala keluarga. Hasil wawancara didapatkan data bahwa ada sebagian keluarga yang masih meyakini pengobatan tradisional, sehingga ada beberapa dukun, dukun bayi, dan tukang pijat yang masih dipercaya oleh masyarakat Desa Rambah Tengah Hilir. Sekretaris Desa menyebutkan bahwa 30\% masyarakat Desa Rambah Tengah Hilir lebih memilih pengobatan tradisional dibandingkan dengan pengobatan medis, hal ini diperkuat oleh hasil wawancara dengan tokoh masyarakat dan masyarakat setempat tentang pengobatan tradisional. Pengobatan tradisional umumnya dilakukan dirumah warga yang membutuhkan pengobatan dan tidak tertutup kemungkinan di rumah dukun, dukun bayi, dan tukang pijat setempat.

Alasan masyarakat di Desa Rambah Tengah Hilir lebih memilih menggunakan pengobatan tradisional karena kurang mendapatkan penyuluhan pengobatan, fasilitas kesehatan yang jauh dari jangkaun desa, pembayarannya lebih murah, praktis, dan dapat menggunakan pembayaran selain uang seperti rokok, gula, kopi, dan lain-lain. Selain itu tingkat pendidikan masyarakat yang masih rendah dan kepercayan 
masyarakat terhadap kebudayaan yang masih tinggi menjadikan pengobatan tradisional ini sebagai alternatif bagi masyarakat untuk memperoleh kesehatan. Keyakinan masyarakat terhadap pengobatan tradisional tersebut dapat mempengaruhi pengambilan keputusan kepala keluarga dalam memilih pengobatan.

Pada penelitian ini variabel yang akan diteliti ada 4 yaitu: pengetahuan, sikap, perilaku kepala keluarga dan pengambilan keputusan pengobatan tradisional. Perilaku seseorang dalam pengambilan keputusan berhubungan dengan pengetahuan seseorang dalam melihat suatu masalah. Variabel ini akan diteliti dengan cross sectional yaitu mengetahui hubungan variabel-variabel yang diukur satu kali waktu (Sastroasmoro, 1995). Melihat fenomena diatas, peneliti tertarik untuk meneliti hubungan pengetahuan, sikap, perilaku kepala keluarga dalam pengambilan keputusan pada pengobatan tradisional di Desa Rambah Tengah Hilir Kecamatan Rambah Kabupaten Rokan Hulu, Riau Tahun 2009.

\section{METODE PENELITIAN}

Penelitian ini merupakan penelitian Observational Analitik dengan menggunakan rancangan penelitian Cross Sectional. Populasi dalam penelitian ini adalah seluruh kepala keluarga yang berdomisili di Desa Rambah Tengah Hilir yang berjumlah 604 kepala keluarga. Sampel dalam penelitian ini merupakan bagian dari populasi teknik sampling yang digunakan adalah probability sampling dengan pendekatan multistage random sampling dan berjumlah 86 responden.

Alat ukur dalam penelitian ini adalah kuesioner. Kuesioner digunakan untuk memperoleh data primer atau informasi dari variabel-variabel yang diteliti.

Pengolahan data yang dilakukan dengan bantuan komputerisasi.

Analisis data meliputi analsis univariat dan bivariat. Adapun langkah-langkah dalam analisis penelitian ini adalah:

a. Analisis univariat yaitu secara deskriptif dengan menggunakan tabel distribusi frekuensi.

b. Analisis bivariat yaitu secara analitik untuk mengetahui hubungan antara dua variabel dengan uji chi-square.

\section{HASIL PENELITIAN}

\section{Deskripsi Subjek Penelitian (Analisis Univariat)}

a. Karakteristik Responden Berdasarkan Umur

Karakteristik responden berdasarkan umur disajikan dalam tabel 1 yaitu sebagai berikut:

Tabel 1. Karakteristik Distribusi Responden Berdasarkan Umur Kepala Keluarga di Desa Rambah Tengah Hilir Tahun 2009

\begin{tabular}{|l|c|c|}
\hline Umur & Frekuensi & Persentase (\%) \\
\hline $25-30$ & 7 & 8.1 \\
\hline $31-35$ & 14 & 16.3 \\
\hline $36-40$ & 12 & 14.0 \\
\hline
\end{tabular}




\begin{tabular}{|l|l|l|}
\hline $41-45$ & 12 & 14.0 \\
\hline $46-50$ & 15 & 17.4 \\
\hline $51-55$ & 6 & 7.0 \\
\hline $56-60$ & 20 & 23.3 \\
\hline Jumlah & 86 & 100.0 \\
\hline
\end{tabular}

Berdasarkan tabel 1, diketahui bahwa dari 86 responden yang paling banyak adalah berusia 56-60 tahun, yaitu $20(23,3 \%)$ responden, dan responden yang paling sedikit adalah responden yang berusia 51-55 tahun sebanyak $6(7,0 \%)$ responden.

b. Karakteristik Responden Berdasarkan Pendidikan

Karakteristik responden berdasarkan pendidikan disajikan dalam tabel 2 yaitu sebagai berikut:

Tabel 2. Karakteristik Distribusi Responden Berdasarkan Pendidikan di Desa Rambah Tengah Hilir Tahun 2009

\begin{tabular}{|l|l|l|}
\hline Pendidikan & Frekuensi & Persentase(\%) \\
\hline Tidak Sekolah & 2 & 2.3 \\
\hline SD & 54 & 62.8 \\
\hline SLTP & 14 & 16.3 \\
\hline SLTA & 16 & 18.6 \\
\hline Jumlah & 86 & 100.0 \\
\hline
\end{tabular}

Berdasarkan tabel 2, diketahui bahwa dari 86 responden yang diteliti, sebagian besar berpendidikan SD yaitu sejumlah 54 (62,8\%) responden dan responden yang pendidikannya paling sedikit yaitu Tidak Sekolah $2(2,3 \%)$.

c. Karakteristik Responden Berdasarkan Tingkat Pekerjaan

Karakteristik responden berdasarkan pekerjaan disajikan dalam tabel 3 yaitu sebagai berikut:

Tabel 3. Karakteristik Distribusi Responden Berdasarkan Tingkat Pekerjaan di Desa Rambah Tengah Hilir Tahun 2009

\begin{tabular}{|l|l|l|}
\hline Pekerjaan & Frekuensi & Persentase (\%) \\
\hline Petani & 63 & 73.3 \\
\hline Wiraswasta & 22 & 25.6 \\
\hline Lainnya & 1 & 1.2 \\
\hline Jumlah & 86 & 100.0 \\
\hline
\end{tabular}

Berdasarkan tabel 3, diketahui bahwa dari 86 responden yang diteliti yang paling banyak adalah responden yang bekerja sebagai petani sebanyak 63

KES MAS Vol. 5, No. 3, September 2011: 162-232 
$(73,3 \%)$ responden dan paling sedikit adalah pekerjaan lainnya sebanyak $1(1,2 \%)$ responden.

d. Tingkat Pengetahuan Responden

Berdasarkan pengetahuan responden dapat dilihat pada tabel. 4 berikut.

Tabel 4. Distribusi Responden Berdasarkan Pengetahuan di Desa Rambah Tengah Hilir Tahun 2009

\begin{tabular}{|l|l|l|}
\hline Tingkat Pengetahuan & Frekuensi & Presentase (\%) \\
\hline Baik & 56 & 65.1 \\
\hline Kurang & 30 & 34.9 \\
\hline Jumlah & 86 & 100.0 \\
\hline
\end{tabular}

Berdasarkan tabel 4 . dari 86 responden yang diteliti terlihat bahwa tingkat pengetahuan kepala keluarga tentang pengobatan tradisional sebanyak $56(65,1 \%)$ responden yang mengetahui tentang pengobatan tradisional dan sebanyak 30 responden (34,9\%) mempunyai pengetahuan yang kurang tentang pengobatan tradisional.

e. Sikap Responden

Berdasarkan sikap responden dapat dilihat pada tabel 5. berikut.

Tabel 5. Distribusi Responden Berdasarkan Sikap di Desa Rambah Tengah Hilir Tahun 2009

\begin{tabular}{|l|l|l|}
\hline Sikap & Frekuensi & Presentase (\%) \\
\hline Baik & 52 & 60.5 \\
\hline Kurang & 34 & 39.5 \\
\hline Jumlah & 86 & 100.0 \\
\hline
\end{tabular}

Berdasarkan tabel 5 . dari 86 responden yang diteliti terlihat bahwa sikap kepala keluarga untuk pengobatan tradisional yaitu sebesar 52 $(60,5 \%)$ responden, sedangkan $34(39.5 \%)$ responden mempunyai sikap yang kurang terhadap pengobatan tradisional.

f. Perilaku Responden

Berdasarkan perilaku responden dapat dilihat pada tabel 6. berikut.

Tabel 6. Distribusi Responden Berdasarkan Perilaku di Desa Rambah Tengah Hilir Tahun 2009

\begin{tabular}{|l|l|l|}
\hline Perilaku & Jumlah & Presentase (\%) \\
\hline Baik & 57 & 66.3 \\
\hline Kurang & 29 & 33.7 \\
\hline Jumlah & 86 & 100.0 \\
\hline
\end{tabular}

Berdasarkan tabel 6 . dari 86 responden yang diteliti terlihat bahwa perilaku kepala keluarga untuk pengobatan tradisional sebesar $57(66,3 \%)$ responden, sedangkan $29(33,7 \%)$ responden mempunyai perilaku kurang terhadap pengobatan tradisional. 
g. Pengambilan Keputusan Pengobatan tradisional

Berdasarkan pengambilan keputusan pengobatan tradisional responden dapat dilihat pada tabel 7 . berikut.

Tabel 7. Distribusi Responden Berdasarkan Pengambilan Keputusan Pengobatan Tradisional di Desa Rambah Tengah Hilir Tahun 2009

\begin{tabular}{|l|l|l|}
\hline $\begin{array}{l}\text { Pengambilan keputusan } \\
\text { pengobatan tradisional }\end{array}$ & Jumlah & Presentase (\%) \\
\hline Ya & 59 & 68,6 \\
\hline Tidak & 27 & 31,4 \\
\hline Jumlah & 86 & 100.0 \\
\hline
\end{tabular}

Berdasarkan tabel 7 . dari 86 responden yang diteliti terlihat bahwa pengambilan keputusan pengobatan tradisional 59 (68,6\%) responden, sedangkan $27(31,4 \%)$ responden mempunyai perilaku kurang terhadap pengobatan tradisional.

\section{Analisis Hubungan Antara 2 Variabel (Analisis Bivariat)}

1. Hubungan Pengetahuan Kepala Keluarga dengan Pengambilan Keputusan Pengobatan Tradisional.

Tabel 10. Hubungan Pengetahuan Kepala Keluarga dengan Pengambilan Keputusan Pengobatan Tradisional di Desa Rambah Tengah Hilir Tahun 2009.

\begin{tabular}{|c|c|c|c|c|c|c|c|}
\hline \multirow[t]{3}{*}{$\begin{array}{l}\text { Pengetahuan } \\
\text { Kepala Keluarga }\end{array}$} & \multicolumn{4}{|c|}{$\begin{array}{l}\text { Pengambilan Keputusan } \\
\text { Pengobatan Tradisional }\end{array}$} & \multirow{2}{*}{\multicolumn{2}{|c|}{ Total }} & \multirow[t]{3}{*}{$P$ value } \\
\hline & \multicolumn{2}{|c|}{$\mathrm{Ya}$} & \multicolumn{2}{|c|}{ Tidak } & & & \\
\hline & $\overline{\mathbf{N}}$ & $\%$ & $\mathbf{N}$ & $\%$ & $\mathbf{N}$ & $\%$ & \\
\hline $\begin{array}{l}\text { Baik } \\
\text { Kurang }\end{array}$ & 45 & $\begin{array}{l}52.3 \\
16,3\end{array}$ & 11 & $\begin{array}{l}12,8 \\
18,6\end{array}$ & 56 & $\begin{array}{l}65,1 \\
34,9\end{array}$ & 0,003 \\
\hline Total & 59 & 68,6 & 17 & 31,4 & 86 & 100 & \\
\hline
\end{tabular}

Hubungan pengetahuan kepala keluarga dengan pengambilan keputusan pengobatan tradisional dapat dilihat pada tabel 10. Hasil penelitian didapatkan bahwa 56 responden $(65,1 \%)$ yang memiliki pengetahuan tentang pengobatan tradisional, terdapat $45(52,3 \%)$ responden yang menggunakan pengobatan tradisional, sedangkan dari $30(34,9 \%)$ responden yang memiliki pengetahuan kurang tentang pengobatan tradisional, terdapat $14(16.3 \%)$ responden yang menggunakan pengobatan tradisional. Dari hasil tersebut secara persentase, responden yang memiliki pengetahuan tentang pengobatan tradisional lebih banyak menggunakan pengobatan tradisional dibandingkan dengan responden yang kurang dalam pengetahuan pengobatan tradisional.

Hasil uji statistik didapatkan nilai $p=0,003$ pada $\alpha=5$ persen, yang dapat diartikan terdapat hubungan yang signifikan antara pengetahuan kepala keluarga dengan pengambilan keputusan pengobatan tradisional, dan secara statistik bermakna.

KES MAS Vol. 5, No. 3, September 2011: 162-232 
2. Hubungan Sikap Kepala Keluarga dengan Pengambilan Keputusan Pengobatan Tradisional di Desa Rambah Tengah Hilir.

Tabel 11. Hubungan Sikap Kepala Keluarga dengan Pengambilan Keputusan Pengobatan Tradisional di Desa Rambah Tengah Hilir Tahun 2009

\begin{tabular}{|c|c|c|c|c|c|c|c|}
\hline \multirow{3}{*}{$\begin{array}{l}\text { Sikap Kepala } \\
\text { Keluarga }\end{array}$} & \multicolumn{4}{|c|}{$\begin{array}{l}\text { Pengambilan Keputusan } \\
\text { Pengobatan Tradisional }\end{array}$} & \multirow{2}{*}{\multicolumn{2}{|c|}{ Total }} & \multirow[t]{3}{*}{$P$ value } \\
\hline & \multicolumn{2}{|c|}{$\mathrm{Ya}$} & \multicolumn{2}{|c|}{ Tidak } & & & \\
\hline & $\overline{\mathbf{N}}$ & $\%$ & $\overline{\mathbf{N}}$ & $\%$ & $\overline{\mathbf{N}}$ & $\%$ & \\
\hline Baik & 47 & 54.7 & 5 & 5,8 & 52 & 60,5 & 0000 \\
\hline Kurang & 12 & 14,0 & 22 & 25,6 & 34 & 39,5 & \\
\hline Total & 59 & $\overline{68,6}$ & 17 & 31,4 & 86 & 100 & \\
\hline
\end{tabular}

Hubungan sikap kepala keluarga dengan pengambilan keputusan pengobatan tradisional dapat dilihat pada tabel 11. Hasil penelitian didapatkan bahwa 52 responden $(60,5 \%)$ yang memiliki sikap tentang pengobatan tradisional, terdapat $47 \quad(54,7 \%)$ responden yang menggunakan pengobatan tradisional, sedangkan dari 34 (39,5\%) responden yang memiliki sikap kurang, terdapat $12(14,0)$ responden yang menggunakan pengobatan tradisional. Dari hasil tersebut secara persentase, responden yang memiliki sikap tentang pengobatan tradisional lebih banyak menggunakan pengobatan tradisional dibandingkan dengan responden yang kurang dalam sikap pengobatan tradisional.

Hasil uji statistik didapatkan nilai $p=0,000$ pada $\alpha=5$ persen, yang dapat diartikan terdapat hubungan yang signifikan antara sikap kepala keluarga dengan pengambilan keputusan pengobatan tradisional, dan secara statistik bermakna.

3. Hubungan Perilaku Kepala Keluarga dengan Pengambilan Keputusan Pengobatan Tradisional di Desa Rambah Tengah Hilir.

Tabel 12. Hubungan Perilaku Kepala Keluarga dengan Pengambilan Keputusan Pengobatan Tradisional di Desa Rambah Tengah Hilir Tahun 2009

\begin{tabular}{|c|c|c|c|c|c|c|c|}
\hline \multirow[t]{3}{*}{$\begin{array}{l}\text { Perilaku Kepala } \\
\text { Keluarga }\end{array}$} & \multicolumn{4}{|c|}{$\begin{array}{l}\text { Pengambilan Keputusan } \\
\text { Pengobatan Tradisional }\end{array}$} & \multirow{2}{*}{\multicolumn{2}{|c|}{ Total }} & \multirow[t]{3}{*}{$P$ value } \\
\hline & \multicolumn{2}{|c|}{ Ya } & \multicolumn{2}{|c|}{ Tidak } & & & \\
\hline & $\mathbf{N}$ & $\%$ & $\mathbf{N}$ & $\%$ & $\mathbf{N}$ & $\%$ & \\
\hline $\begin{array}{l}\text { Baik } \\
\text { Kurang }\end{array}$ & $\begin{array}{l}47 \\
12\end{array}$ & $\begin{array}{l}54.7 \\
14,0\end{array}$ & $\begin{array}{l}10 \\
17\end{array}$ & $\begin{array}{l}11,6 \\
19.8\end{array}$ & $\begin{array}{l}57 \\
29\end{array}$ & $\begin{array}{l}66,3 \\
33,7\end{array}$ & 0,000 \\
\hline Total & 59 & 68,6 & 17 & 31,4 & 86 & 100 & \\
\hline
\end{tabular}


Hubungan perilaku kepala keluarga dengan pengambilan keputusan pengobatan tradisional dapat dilihat pada tabel 12. Hasil penelitian didapatkan bahwa 57 responden $(66,3 \%)$ yang memiliki perilaku tentang pengobatan tradisional, terdapat 47 (54,7\%) responden yang menggunakan pengobatan tradisional, sedangkan dari $29 \quad(33,7 \%)$ responden yang memiliki sikap kurang, terdapat $12(14,0)$ responden yang menggunakan pengobatan tradisional. Dari hasil tersebut secara persentase, responden yang memiliki perilaku yang baik tentang pengobatan tradisional lebih banyak menggunakan pengobatan tradisional dibandingkan dengan responden yang kurang dalam sikap pengobatan tradisional.

Hasil uji statistik didapatkan nilai $p=0,000$ pada $\alpha=5$ persen, yang dapat diartikan terdapat hubungan yang signifikan antara perilaku kepala keluarga dengan pengambilan keputusan pengobatan tradisional dan secara statistik bermakna.

\section{PEMBAHASAN}

Berdasarkan hasil penelitian yang dilakukan terhadap 86 responden didapatkan responden yang menggunakan pengobatan tradisional sebesar 59 responden $(68,6 \%)$, sedangkan yang tidak menggunakan pengobatan tradisional sebesar 27 responden $(31,4 \%)$. Hasil ini menunjukkan yang menggunakan pengobatan tradisional di Desa Rambah Tengah Hilir Kecamatan Rambah Kabupaten Rokan Hulu, Riau masih cukup tinggi. Adapun yang diteliti dalam penelitian ini adalah pengetahuan, sikap, dan perilaku kepala keluarga.

1. Hubungan Pengetahuan Kepala Keluarga dengan Pengambilan Keputusan Pengobatan Tradisional di Desa Rambah Tengah Hilir .

Hasil uji statistik Hubungan pengetahuan kepala keluarga dengan pengambilan keputusan pengobatan tradisional dapat dilihat pada tabel 10. Hasil penelitian didapatkan bahwa 56 responden $(65,1 \%)$ yang memiliki pengetahuan yang baik tentang pengobatan tradisional, terdapat 45 responden $(52,3 \%)$ yang menggunakan pengobatan tradisional, didapatkan nilai $p=0,003$ pada $\alpha=5$ persen, berarti dapat disimpulkan ada hubungan yang signifikan antara pengetahuan kepala keluarga dengan pengambilan keputusan pengobatan tradisional dan secara statistik bermakna. Hasil wawancara menunjukkan ternyata responden kurang mendapatkan penyuluhan terhadap pengobatan medis, dan juga pendidikan masyarakat yang sebagian besar berpendidikan rendah sehingga masyarakat lebih cendrung menggunakan pengobatan tradisional.

Pengetahuan merupakan domain yang sangat penting bagi terbentuknya suatu tindakan atau perilaku yang menguntungkan bagi seseorang, khususnya dalam pengambilan keputusan pengobatan. Pengetahuan pada manusia bertujuan untuk dapat menjawab masalah kehidupan manusia, pengetahuan diibaratkan sebagai suatu alat yang dipakai manusia dalam menyelesaikan persoalan yang dihadapi. Pengetahuan merupakan khasanah kekayaan mental secara langsung atau tidak langsung turut memperkaya kehidupan kita. Setiap pengetahuan mempunyai ciri-ciri yang spesifik mengenai apa (ontologi), bagaimana (epistologi), dan untuk siapa (aksiologi) ${ }^{4}$. Hasil penelitin ini sesuai dengan penelitian yang dilakukan oleh Rosita (2003) menunjukkan adanya hubungan yang bermakna antara pengetahuan dengan pengambilan keputusan pengobatan $(p=0,000)$. 
2. Hubungan Sikap Kepala Keluarga dengan Pengambilan Keputusan Pengobatan Tradisional di Desa Rambah Tengah Hilir.

Hasil uji statistik Hubungan sikap kepala keluarga dengan pengambilan keputusan pengobatan tradisional dapat dilihat pada tabel 11. Hasil penelitian didapatkan, 52 responden $(60,5 \%)$ yang memiliki sikap yang baik tentang pengobatan tradisional, terdapat 47 responden $(54,7 \%)$ yang menggunakan pengobatan tradisional, didapatkan nilai $p=0,000$ pada $\alpha=5$ persen, berarti dapat disimpulkan ada hubungan yang signifikan antara sikap kepala keluarga dengan pengambilan keputusan pengobatan tradisional dan secara statistik bermakna. Hasil wawancara menunjukkan ternyata pengobatan tradisional bisa didapatkan sewaktu dibutuhkan, dipercaya karena pengalaman pribadi, tradisi yang turun temurun (kebudayaan), serta pendapatan atau penghasilan keluarga yang rendah.

Sikap (attitude) adalah salah satu predisposisi atau kecenderungan yang relatif stabil dan berlangsung terus menerus untuk bertingkah laku atau merealisasikan dengan satu cara tertentu terhadap pribadi lain, objek, lembaga atau persoalan tertentu. Dilihat dari satu titik pandangan yang sedikit berbeda, sikap merupakan kecenderungan untuk merealisasikan terhadap orang, institusi atau kejadian, baik secara positif maupun negatif 5 .

Hasil penelitian ini sesuai dengan penelitian Hakimi (1999) dan Wijayanti (1999) yang mengatakan bahwa sikap merupakan salah satu variabel penentu dalam pemilihan pengambilan keputusan, tapi bertolak belakang dengan penelitian Rosita (2003) yang menyatakan bahwa sikap hanya berpengaruh $1 \%$ dalam pengambilan keputusan, sedangkan 99\% ditentukan oleh faktor lain. Hasil penelitian yang sama juga ditunjukkan oleh Glagah, dkk (2008) yang menyatakan pengobatan tradisional lebih murah dibandingkan pengobatan medis, obat tradisional memiliki efek samping lebih sedikit, penghasilan masyarakat, pendidikan, dan asal daerah (daerah pedesaan cenderung memilih obat tradisional).

Berbagai faktor yang mempengaruhi pembentukan sikap adalah pengalaman pribadi, kebudayaan, dan orang lain yang dianggap penting. Pembentukan sikap tidak terjadi begitu saja, melainkan sikap terbentuk karena melalui suatu proses tertentu, melalui kontak sosial terus menerus antara individu dengan individu lain disekitarnya demikian pula dalam pengambilan keputusan pengobatan ${ }^{6}$.

Sikap merupakan reaksi atau respon yang masih tertutup dari seseorang terhadap stimulus atau objek. Sikap mempunyai tiga komponen pokok, antara lain: kepercayaan (keyakinan), ide, dan konsep terhadap suatu objek; kehidupan emosional atau evaluasi terhadap suatu objek; kecenderungan untuk bertindak.

3. Hubungan Perilaku Kepala Keluarga dengan Pengambilan Keputusan Pengobatan Tradisional di Desa Rambah Tengah Hilir.

Hasil uji statistik Hubungan perilaku kepala keluarga dengan pengambilan keputusan pengobatan tradisional dapat dilihat pada tabel 12. Hasil penelitian didapatkan bahwa 57 responden $(66,3 \%)$ yang memiliki perilaku tentang pengobatan tradisional, terdapat 47 responden $(54,7 \%)$ yang menggunakan pengobatan tradisional, didapatkan nilai $p=0,000$ pada $\alpha=5$ persen, berarti dapat disimpulkan ada hubungan yang signifikan antara perilaku kepala keluarga dengan pengambilan keputusan pengobatan tradisional dan secara statistik bermakna. Hasil wawancara menunjukkan masyarakat lebih percaya dengan pengobatan tradisional karena lebih murah, praktis, sarana transportasi yang sulit untuk dilalui, kondisi demografi daerah yang jauh dari jangkauan pelayana kesehatan serta faktor lingkungan yang ada pada daerah tersebut.

Faktor lingkungan memiliki kekuatan besar dalam menentukan perilaku bahkan kekuatannya lebih besar dari pada karakteristik individu. Perilaku manusia 
itu ditentukan oleh kekuatan irrasional yang tidak disadari. Penelitian Dyah (2003), mengatakan bahwa faktor pendapatan sangat berpengaruh pada pengambilan keputusan dalam pemilihan pelayanan ANC, semakin tinggi tingkat pendapatan semakin banyak pilihan untuk menggunakan pelayanan ANC.

Perilaku adalah suatu fungsi dari interaksi antara seseorang individu dengan lingkungannya. Perilaku manusia adalah sebagai suatu fungsi dari interaksi antara person atau individu dengan lingkungannya. Ini berarti bahwa seseorang individu dengan lingkungannya menentukan perilaku keduanya secara langsung. Perilaku merupakan hasil dari pengalaman serta interaksi manusia dengan lingkungan yang terwujud dalam bentuk pengetahuan, sikap, dan tindakan ${ }^{7}$.

Penerimaan perilaku baru atau adopsi perilaku didasarkan pada pengetahuan, kesadaran, dan sikap yang positif; bila perilaku tersebut tidak didasarkan oleh pengetahuan dan kesadaran maka perilaku tersebut tidak berlangsung lama. Proses pembentukan keputusan dibagi menjadi empat tahap utama. Pertama individu menerima informasi dan pengetahuan berkaitan dengan suatu ide (knowledge), dimana pengetahuan tersebut menimbulkan minat untuk mengenal lebih jauh tentang topik tersebut. Tahap ini tergantung dari motivasi apakah individu membuat keputusan untuk menerima ide tersebut (persuation). Selanjutnya individu akan meminta dukungan dari lingkungan atas keputusan yang telah diambil (confirmation). Bila lingkungan mendukung maka perilaku yang baru akan dipertahankan (adoption) ${ }^{8}$.

\section{KESIMPULAN}

a. Ada hubungan yang bermakna antara pengetahuan kepala keluarga dengan pengambilan keputusan pengobatan tradisonal di Desa Rambah Tengah Hilir Kecamatan Rambah Kabupaten Rokan Hulu Riau $(p=0,003)$.

b. Ada hubungan yang bermakna antara sikap kepala keluarga dengan pengambilan keputusan pengobatan tradisonal di Desa Rambah Tengah Hilir Kecamatan Rambah Kabupaten Rokan Hulu Riau ( $p=0,000)$.

c. Ada hubungan yang bermakna antara perilaku kepala keluarga dengan pengambilan keputusan pengobatan tradisonal di Desa Rambah Tengah Hilir Kecamatan Rambah Kabupaten Rokan Hulu Riau $(p=0,000)$.

\section{SARAN}

a. Bagi Desa Rambah Tengah Hilir

Perlunya peningkatan peran serta program promosi kesehatan dalam meningkatkan pengetahuan masyarakat tentang pengobatan bukan saja pengobatan tradisional tetapi juga pengobatan secara medis. Seperti upaya penyuluhan yang berkesinambungan kepada masyarakat agar masyarakat tertarik untuk melakukan pengobatan secara medis.

b. Bagi Penelitian

Bagi peneliti selanjutnya diharapkan untuk dapat lebih mendalam penelitian melalui suatu penelitian yang besifat kualitatif untuk memperkuat temuan ditempat penelitian. 


\section{DAFTAR PUSTAKA}

1. Notoatmodjo, S., 2007, Promosi Kesehatan dan IImu Perilaku, Rineka Cipta, Jakarta.

2. Manuaba, I. B. G, 1998, Memahami Kesehatan Reproduksi Wanita. Arcan, Jakarta.

3. Setyowati, S., 2008, Asuhan Keperawatan Keluarga: konsep dan aplikasi kasus, Mitra Cendikia, Yogyakarta.

4. Notoatmodjo, S., 2003, IImu Kesehatan Masyarakat: Prinsip-prinsip Dasar, Rineke Cipta, Jakarta.

5. Chaplin, J.P., 2002, Teknik Penyusunan Skala Pengukuran, Pusat Studi Kependidikan UGM

6. Azwar., S., 2005, Sikap Manusia Teori dan Pengukurannya, Edisi ke 2, Pustaka Pelajar, Yogyakarta.

7. Thoha, M., 2007. Perilaku Organisasi: konsep dasar dan aplikasinya, PT. Rajagrafindo Persada, Jakarta.

8. Sarwono, S., 2004, Sosiologi Kesehatan: beberapa konsep beserta aplikasinya, Cetakan Ketiga, Yogyakarta Gajahmada University Pers. 